\title{
ANALISIS PENCATATAN DAN PELAPORAN PAJAK HOTEL (STUDI PADA DISPENDA BITUNG DAN DISPENDA MANADO)
}

\author{
Mentari G. Kumaat ${ }^{1}$, Sifrid S. Pangemanan ${ }^{2,}$ Heince R. N. Wokas ${ }^{3}$ \\ ${ }^{1,2,3}$ Fakultas Ekonomi dan Bisnis, Jurusan Akuntansi, Universitas Sam Ratulangi, Jl. Kampus Bahu, Manado, \\ 95115, Indonesia \\ E-mail : mentarikumaat32@gmail.com
}

\begin{abstract}
Taxes are one source of state revenue. Local tax is a tax which is entrusted by the central government to be levied and managed by local governments. Local tax is one sector in incereasing local revenue. Hotel taxes included in the tax area. Hotel tax is a potential sector in raising revenue. The purpose this study to know the recording and reporting of hotel tax (study on Dispenda Bitung and Dispenda Manado). The method used is descriptive analysis, the research conducted by collecting data, analyzing the data collected, as well as giving particular faced, and draw conclusions. The data used in this research is secondary data, using all the data obtained from the source. The result show Dispenda Bitung and Dispenda Manado has yet to make its accounting records or journal transaction taxes when receiving payments of hotel taxes, and based on data from the Budget Realization Statement of hotel tax, hotel tax revenue of Manado city is greater than the hote tax revenue of Bitung city.
\end{abstract}

Keywords : analysis, recording and reporting, hotel tax

\section{PENDAHULUAN}

Pertumbuhan ekonomi sangat berpengaruh dalam meningkatkan kesejahteraan dalam berbagai sektor untuk mewujudkan kemandirian suatu bangsa atau negara dalam pembiayaan pembangunan yaitu dengan menggali sumber dana dari dalam negeri. Salah satu sumber pembiayaan pembangunan dalam negeri melalui pajak yang dipungut kepada wajib pajak. Pajak merupakan salah satu bentuk penerimaan negara, bahkan pajak adalah sumber pendapatan negara terbesar. Salah satu sumber pembiayaan pembangunan adalah melalui pajak yang dipungut kepada wajib pajak, karena pajak merupakan iuran rakyat kepada negara berdasarkan ketentuan perundang-undangan perpajakan yang dipungut pemerintah pusat maupun pemerintah daerah.

Pajak daerah adalah salah satu jenis pajak yang dipercayakan oleh pemerintah pusat untuk dipungut oleh pemerintah daerah. Pajak daerah merupakan salah satu pendapatan asli daerah yang dipungut dari masyarakat tanpa mendapatkan imbalan langsung. Pendapatan asli daerah merupakan cermin pertumbuhan ekonomi dalam suatu daerah. Pajak hotel merupakan salah satu jenis pajak yang dipungut oleh pemerintah daerah. Dengan menggali serta meningkatkan potensi pajak daerah, maka pendapatan asli daerah dapat digunakan untuk pembangunan serta peningkatan kesejahteraan masyarakat pada daerah tersebut. Penelitian ini bertujuan untuk mengetahui bagaimana pencatatan dan pelapoan pajak hotel di Dispenda Bitrung dan Dispenda Manado.

\section{TINJAUAN PUSTAKA}

\subsection{Akuntansi}

Huriah Badriah (2015:9) Akuntansi adalah pengukuran, penjabaran, atau pemberian kepastian mengenai informasi yang akan membantu manajer, investor, otoritas pajak dan pembuat keputusan lain untuk membuat alokasi sumberdaya keputusan di dalam perusahaan, organisasi, dan lembaga pemerintahan. Suwardjono dalam Hendra (2014:1), menyatakan 
akuntansi adalah seperangkat pengetahuan dan fungsi yang berkepentingan dengan masalah pengadaan, pengabsahan, pencatatan, pengklasifikasian, pemrosesan, peringkasan, penganalisisan, penginterpretasian dan penyajian secara sistematik informasi yang dapat dipercaya dan berdaya guna tentang transaksi dan kejadian yang bersi fat keuangan yang diperlukan dalam pengelolaan dan pengoperasian suatu unit usaha dan yang diperlukan untuk dasar penyusunan laporan yang harus disampaikan untuk memenuhi pertanggungjawaban pengurusan keuangan dan lainnya.

\subsection{Perpajakan}

Thomas Sumarsen SE (2015:5) Pajak merupakan peranan yang sangat penting dalam kehidupan bernegara khususnya didalam pelaksanaan pembangunan karena pajak merupakan sumber pendapatan negara untuk membiayai semua pengeluaran termasuk pengeluaran pembangunan.

Prof. Dr. Mardiasmo, MBA., Ak, (2013:1-2) ada dua fungsi pajak :

1. Fungsi Budgeter

Pajak sebagai sumber dana bagi pemerintah untuk membiayai pengeluaranpengeluarannya

2. Fungsi mengatur (regulerend)

Pajak sebagai alat untuk mengatur atau melaksanakan kebijaksanaan pemerintah dalam bidang sosial dan ekonomi.

Sistem pemungutan pajak menurut Mardiasmo dalam Watung (2016:1) adalah sebagai berikut:

\section{Official Assement System}

Suatu sistem pemungutan yang memberi wewenang kepada pemerintah (fiskus) untuk menentukan besarnya pajak yang terutang oleh Wajib Pajak.

2. Self Assessment System

Suatu sistem pemungutan yang memberi wewenang kepada Wajib Pajak untuk menentukan sendiri besarnya pajak yang terutang. Sehingga dengan sistem ini Wajib Pajak harus aktif untuk menghitung, menyetor dan melaporkan kepada Kantor Pelayanan Pajak (KPP).

\section{Witholding System}

Suatu sistem pemungutan pajak yang memberi wewenang kepada pihak ketiga bukan fiskus dan bukan wajib pajak yang bersangkutan untuk menentukan besarnya pajak yang terutang oleh wajib pajak.

Syarat pemungutan pajak menurut Waluyo dalam Wungkar (2016) adalah:

1. Pemungutan pajak harus adil (syarat keadilan).

Sesuai dengan tujuan hukum, yakni mencapai keadilan. Undang-undang dan pelaksanaan pemungutan harus adil. Adil dalam perundang-undangan diantaranya mengenakan pajak secara umum dan merata, serta disesuaikan dengan kemampuan masing-masing. Sedangkan adil dalam pelaksanaannya yakni dengan memberikan hak bagi wajib pajak untuk mengajukan keberatan, penundaan dalam pembayaran dan mengajukan banding kepada pertimbangan pajak.

2. Pemungutan pajak harus berdasarkan Undang-undang (syarat yuridis). Di Indonesia, pajak diatur dalam UUD 1945 pasal 23 ayat 2. Hal ini memberikan jaminan hukum untuk menyatakan keadilan, baik Negara maupun warganya.

3. Tidak mengganggu perekonomian (syarat ekonomi).

Pemungutan tidak boleh mengganggu kelancaran kegiatan produksi maupun perdagangan, sehingga tidak menimbulkan kelesuan perekonomian masyarakat.

4. Pemungutan pajak harus efisien (syarat financial). 
Sesuai fungsi budgeter, biaya pemungutan pajak harus dapat ditekan sehingga lebih rendah dari hasil pemungutannya.

5. System pemungutan pajak harus sederhana.

System pemungutan sederhana akan memudahkan dalam mendorong masyarakat untuk memenuhi kewajiban perpajaknnya. Syarat ini telah dipenuhi oleh undangundang perpajakan yang baru.

Menurut Mardiasmo (2011: 5), Pajak dapat dikelompokkan menjadi:

Menurut golongan

a. Pajak langsung, adalah pajak yang pembebanannya tidak dapat dilimpahkan ke pihak lain, tetapi harus menjadi beban langsung Wajib Pajak yang bersangkutan. Sebagai contoh, Pajak Penghasilan.

b. Pajak tidak langsung, adalah pajak yang pembebanannya dapat dilimpahkan ke pihak lain. Sebagai contoh Pajak Pertambahan Nilai.

Menurut sifat

Pembagian pajak menurut sifat dimaksudkan untuk pembedaan dan pembagiannya berdasarkan ciri-ciri prinsip:

a. Pajak sujektif, adalah pajak yang berpangkal atau berdasarkan pada subjeknya yang selanjutnya dicari syarat objektifnya, dalam arti memperhatikan keadaan dari wajib pajak. Contohnya, Pajak Penghasilan.

b. Pajak objektif, adalah pajak yang berpangkal atau berdasarkan pada objeknya, tanpa memperhatikan keadaan diri wajib pajak. Contohnya, Pajak Pertambahan Nilai (PPN) dan Pajak Penjualan atas Barang Mewah.

Menurut Pemungut dan Pengelolanya

a. Pajak pusat, adalah pajak yang dipungut oleh pemerintah pusat dan digunakan untuk membiayai rumah tangga negara. Contohnya, Pajak Penghasilan, Pajak Pertambahan Nilai dan Pajak atas Penjualan Barang Mewah, Pajak Bumi dan Bangunan, dan Bea Materai.

b. Pajak daerah, adalah pajak yang dipungut pemerintah daerah dan digunakan untuk membiayai rumah tangga daerah. Contohnya, Pajak Reklame, Pajak Hiburan.

\subsection{Jenis-jenis Pajak}

Secara umum jenis pajak dibedakan menjadi pajak pusat dan pajak daerah. Contoh dari pajak pusat adalah:

1. Pajak Penghasilan $(\mathrm{PPh})$

2. Pajak Pertambahan Nilai (PPN)

3. Pajak Penjualan Barang Mewah (PPnBM)

4. Pajak Bumi dan Bangunan (PBB)

Khusus jenis pajak Pajak Bumi dan Bangunan (PBB) mulai tahun 2012 pengelolaannya disebagian dialihkan kepada Pemerintah Daerah (Pemda).

Pajak daerah dibedakan menjadi pajak provinsi dan pajak kabupaten/kota. Berbagai pajak provinsi antara lain adalah: pajak kendaraan bermotor dan kendaraan diatas air, bea balik nama kendaraan bermotor, pajak bahan bakar kendaraan bermotor, pajak air permukaan, dan pajak rokok. Berbagai pajak kabupaten/kota antara lain adalah: pajak hotel, pajak restoran, pajak hiburan, pajak reklame, pajak penerangan jalan, pajak mineral bukan logam dan batuan, pajak parkir, pajak air tanah, pajak sarang burung wallet, pajak bumi dan bangunan pedesaan dan perkotaan, dan bea perolehan hak atas tanah dan bangunan. (Djoko Muljono 2010:9-10). 


\subsection{Pajak Daerah}

Pajak daerah menurut Mardiasmo (2013:12) adalah iuran yang dilakukan oleh Orang Pribadi atau badan kepada daerah tanpa imbalan langsung yang seimbang, yang dapat dipaksakan berdasarkan Peraturan perundang-undangan yang berlaku, yang digunakan untuk membiayai penyelenggaraan pemerintah daerah. Pajak daerah adalah pajak yang pengelolaannya ditangani oleh pemerintah daerah, dalam hal ini kepala daerah, gubernur, walikota, bupati. Pajak daerah dibedakan sesuai yang mengelolanya yaitu Pajak Provinsi dan Pajak Kabupaten/Kota.

\section{5 Pajak Hotel}

Dalam Peraturan Daerah Nomor 1 Tahun 2013 kota Bitung tentang Pajak Daerah dan dalam Peraturan Daerah Nomor 2 Tahun 2011 mengartikan Hotel adalah fasilitas penyedia jasa penginapan/peristirahatan termasuk jasa terkait lainnya dengan dipungut bayaran, yang mencakup juga motel, losmen, gubuk pariwisata, wisma pariwisata, pesanggrahan, rumah penginapan dan sejenisnya serta rumah kos dengan jumlah kamar lebih dari sepuluh (pasal 1 ayat 13). Sedangkan Pajak Hotel adalah pajak atas pelayanan yang disediakan oleh hotel. Setiap pelayanan yang disediakan hotel dipungut pajak dengan nama pajak hotel (pasal 1 ayat 11)

Setiap pelayanan yang disediakan hotel dipungut pajak dengan nama pajak hotel (pasal 3). Objek pajak hotel adalah pelayanan yang disediakan oleh hotel dengan pembayaran, termasuk jasa penunjang sebagai kelengkapan hotel yang sifatnya memberikan kemudahan dan kenyamanan termasuk fasilitas olahraga dan hiburan. Jasa penunjang sebagaimana dimaksud pada ayat 1 adalah fasilitas telepon, faximile, telex, internet, fotocopy, pelayanan cuci setrika, transportasi dan fasilitas lainnyayang disediakan atau dikelola hotel (pasal 4 ayat 2). Tidak termasuk pajak hotel adalah : jasa tempat tinggal yang diselenggarakan oleh pemerintah atau pemerintah daerah, jasa sewa apartemen, kondominium dan sejenisnya, jasa tempat tinggal di pusat pendidikan atau kegiatan keagamaan, jasa tempat tinggal di rumah sakit, asrama perawat, panti jompo, panti asuhan, dan panti sosial lainnya yang sejenis, dan jasa biro perjalanan atau perjalanan wisata yang diselenggarakan oleh hotel yang dapat dimanfaatkan oleh umum (pasal 4 ayat 3 ).

Subjek pajak hotel ialah orang pribadi atau badan yang melakukan pembayaran kepada orang pribadi atau badan yang mengusahakan hotel (pasal 5 ayat 1). Wajib pajak hotel adalah orang pribadi atau badan yang mengusahakan hotel ( pasal 5 ayat 2).

Dasar pengenaan pajak hotel adalah jumlah pembayaran yang diterima atau yang seharusnya dibayar kepada hotel. Di kota Bitung menurut Peraturan Daerah Nomor 1 Tahun 2013 Pasal 27 ayat 1 menyatakan tarif pajak hotel ditetapkan sebesar $10 \%$ (termasuk pajak rumah kos dengan kamar lebih dari 10). Di kota Manado menurut Peraturan Daerah Nomor 2 Tahun 2011 menyatakan tarif pajak hotel ditetapkan sebesar $10 \%$ (pasal 13), dan rumah kos dengan jumlah kamar lebih dari 10 sebesar $5 \%$ (pasal 7). Pajak hotel merupakan jenis pajak yang dibayar sendiri oleh wajib pajak.

\subsection{Pendapatan Asli Daerah}

Pengertian Pendapatan Asli Daerah menurut Undang-Undang No. 28 Tahun 2009 yaitu sumber keuangan daerah yang digali dari wilayah daerah yang bersangkutan yang terdiri dari hasil pajak daerah, hasil retribusi daerah, hasil pengelolaan kekayaan daerah yang dipisahkan dan lain-lain pendapatan asli daerah yang sah. Pendapatan daerah adalah semua hak daerah yang diakui sebagai nilai kekayaan bersih dalam periode anggaran tertentu. Sesuai dengan Undang-Undang Nomor 32 Tahun 2004 Tentang Pemerintahan Daerah, bahwa pendapatan daerah berasal dari penerimaan dari dana perimbangan pusat dan daerah, juga 
yang berasal dari daerah itu sendiri yaitu pendapatan asli daerah serta lain-lain pendapatan yang sah.

Berdasarkan Undang-Undang Nomor 33 Tahun 2004 Tentang Perimbangan Keuangan Pemerintah Pusat dan Daerah dalam Pasal 3 huruf (a), sumber-sumber pendapatan asli daerah tersebut adalah:

1. Pajak Daerah

2. Retribusi Daerah

3. Hasil Perusahaan Milik Daerah dan Hasil Pengelolaan Kekayaan Daerah yang dipisahkan

4. Lain-lain Pendapatan Asli Daerah yang sah

\section{METODE PENELITIAN}

\subsection{Jenis Penelitian}

Jenis penelitian yang digunakan dalam penelitian ini adalah penelitian kualitatif deskriptif. Metode deskriptif yatu metode yang digunakan untuk menggambarkan atau menganalisis suatu hasil penelitian tetap tidak digunakan untuk kesimpulan yang lebih luas (Sugiyono 2011:21).

\subsection{Tempat dan Waktu Penelitian}

Penelitian dilakukan di Dinas Pendapatan Daerah Kota Bitung dan Dinas Pendapatan Daerah Kota Manado. Waktu Penelitian dilakukan pada November 2016 sampai dengan selesai.

\subsection{Prosedur Penelitian}

Langkah-langkah dalam penelitian yaitu: mengidentifikasi masalah, merumuskan maasaalah, mengumpulkan data, menganalisis data, dan mengambil hasil penelitian.

\subsection{Metode Pengumpulan Data}

Jenis data yang digunakan dalam penelitian ini yaitu data kualitatif berupa penjelasan yang diperoleh dari Dinas Pendapatan Daerah Kota Bitung dan Kota Manado berupa sejarah singkat dan informasi lainnya yang relevan dengan penulisan ini, dan data kuantitatif yaitu data yang berbentuk angka-angka yang berupa data pajak hotel.

Sumber data yang digunakan dalam penelitian ini adalah data sekunder yaitu dengan menggunakan semua data yang diperoleh dari sumber.

\subsection{Metode Analisis}

Metode analisis data yang digunakan penelitian ini adalah metode analisis deskriptif dimana penelitian dilakukan dengan mengumpulkan, dan menganalisa data yang dikumpulkan serta memberi keterangan-keterangan yang dihadapi.

\section{Hasil Penelitian dan Pembahasan}

\subsection{Gambaran Umum Objek Penelitian}

Dinas pendapatan daerah kota Bitung merupakan Unit kerja di lingkungan pemerintah kota Bitung yang melaksanakan tugasnya di bidang pendapatan daerah. Sesuai dengan tugasnya, maka dispenda kota Bitung merupakan coordinator pendapatan yang dilakukan oleh semua unit pengelola pendapatan yang ada di kota Bitung. Visi dari Dinas Pendapatan Daerah Kota Bitung terwujudnya pengelolaan pendapatan daerah yang berkualitas dan partisipatif. Misi meningkatkan kualitas pengelolaan pendapatan daerah sesuai dengan ketentuan yang berlaku. Optimalisasi pendapatan daerah melalui intensifikasi dan ekstensifikasi yang terukur, berkualitas dan berkeadilan. Meningkatkan kualitas sumber daya aparatur bidang pendapatan sesuai dengan standar pelayanan. Dan Dinas Pendapatan Daerah kota Manado memiliki tugas pokok yaitu melaksanakan urusan pemerintahan daerah berdasarkan asas otonomi dan tugas pembantuan di bidang pendapatan daerah. 


\subsection{Hasil Penelitian}

Table 4.1 Laporan Penerimaan Pajak Hotel Kota Bitung

\begin{tabular}{|l|l|l|l|}
\hline Tahun & Target & Realisasi & Persentase (\%) \\
\hline 2011 & Rp. 1.100 .000 .000 & Rp. 1.375 .080 .887 & 125,01 \\
\hline 2012 & Rp. 1.290 .000 .000 & Rp. 1.457 .025 .208 & 112,95 \\
\hline 2013 & Rp. 1.500 .000 .000 & Rp. 1.800 .124 .842 & 120,01 \\
\hline 2014 & Rp. 1.800 .000 .000 & Rp. 2.079 .360 .152 & 115,52 \\
\hline 2015 & Rp. 1.500 .000 .000 & Rp. 1.695 .607 .242 & 113,04 \\
\hline
\end{tabular}

Pada table 1 dapat dilihat target dan realisasi pajak hotel di kota Bitung tahun anggaran 2011-2015. Pada tahun 2011 target Rp. 1.100.000.000 dengan realisasi Rp. 1.375.080.887, tahun 2012 target Rp. 1.290.000.000 dengan realisasi Rp. 1.457.025.208, tahun 2013 target Rp. 1.500.000.000 dengan realisasi Rp. 1.800.124.842, tahun 2014 target Rp. 1.800.000.000 dengan realisasi Rp. 2.079.360.152, dan pada tahun 2015 target Rp. 1.500.000.000 dengan realisasi Rp. 1.695.607.242. Penerimaan pajak hotel terendah terjadi pada tahun 2011 dengan realisasi Rp. 1.375.080.887. Penerimaan pajak hotel tertinggi terjadi pada tahun 2014 dengan realisasi Rp. 2.079.360.152.

Table 4.2 Laporan Penerimaan Pajak Hotel Kota Manado

\begin{tabular}{|l|l|l|l|}
\hline Tahun & Target & Realisasi & Persentase (\%) \\
\hline 2011 & Rp. 12.063 .818 .000 & Rp. 10.424 .824 .091 & 86,41 \\
\hline 2012 & Rp. 14.170 .223 .000 & Rp. 14.372 .806 .936 & 101,43 \\
\hline 2013 & Rp. 15.000 .000 .000 & Rp. 17.129 .842 .717 & 114,20 \\
\hline 2014 & Rp. 15.999 .999 .900 & Rp. 17.449 .408 .116 & 109,06 \\
\hline 2015 & Rp. 18.000 .000 .000 & Rp. 18.168 .799 .451 & 100,94 \\
\hline
\end{tabular}

Pada table 2 dapat dilihat target dan realisasi pajak di kota Manado tahun anggaran 2011-2015. Pada tahun 2011 target Rp. 12.063.818.000 dengan realisasi Rp. 10.424.824.091, tahun 2012 target Rp. 14.170.223.000 dengan realisasi Rp. 14.372.806.936, tahun 2013 target Rp. 15.000.000.000 dengan realisasi Rp. 17.129.842.717, tahun 2014 target Rp. 15.999.999.900 dengan realisasi Rp. 17.449.408.116, dan pada tahun target Rp. 18.000.000.000 dengan realisasi Rp. 18.168.799.451. Penerimaan pajak hotel terendah terjadi pada tahun 2011 dengan realisasi Rp. 10.424.824.091. Penerimaan pajak hotel tertinggi terjadi pada tahun 2015 dengan realisasi Rp. 18.168.799.451.

\subsection{Pembahasan}

Jumlah wajib pajak hotel kota Bitung yang terdaftar di Dinas Pendapatan Daerah kota Bitung yaitu berjumlah 103 wajib pajak.. Tarif pajak hotel ditetapkan sebesar 10\% termasuk pajak rumah kos sebesar $10 \%$. Besaran pokok pajak hotel yang terhutang dihitung dengan cara mengalikan tarif dengan dasar pengenaan pajak. (Perda No. 1 Tahun 2013 Pasal 27)

Jumlah wajib pajak hotel kota Manado yang terdaftar di Dinas Pendapatan Daerah kota Manado yaitu berjumlah 482 wajib pajak. Dasar pengenaan pajak hotel adalah jumlah pembayaran yang diterima atau yang seharusnya dibayar kepada hotel. Tarif pajak hotel di tetapkan sebesar $10 \%$, dan untuk rumah kos dengan jumlah kamar lebih dari sepuluh di tetapkan sebesar 5\%. (Perda No. 2 Tahun 2011 Pasal 7)

Tata Cara Perhitungan Pajak Hotel

Pajak terutang $=$ Tarif pajak $\mathrm{x}$ Dasar pengenaan pajak 
Contoh perhitungan pajak hotel adalah pajak dihitung sendiri oleh wajib pajak (self assessment) misalnya Hotel A mendapat omset dalam satu bulan sebesar Rp. 80.000.000.

Jadi pendapatan Hotel A sebesar Rp. 80.000.000.

Dan tariff pajak hotel yang ditetapkan pemerintah daerah sebesar $10 \%$ maka besaran pajak terutang yang harus dibayar oleh pengusaha hotel ke kas daerah adalah sebagai berikut:

Masa pajak tanggal $1 \mathrm{~s} / \mathrm{d} 31$ januari

Dasar pengenaan pajak (jumlah pembayaran Rp.80.000.000 yang diterima)

Tarif pajak $10 \%$

Rp. $80.000 .000 \times 10 \%=$ Rp. 8.000 .000

Besarnya pajak yang harus dibayar oleh hotel A adalah sebesar Rp. 8.000.000

\section{Pencatatan Penerimaan Pajak Hotel}

Untuk pencatatan pajak hotel di Dispenda Kota Bitung

1. Pada tanggal 20 september 2016 diterima pembayaran pajak dari Sri Mega Ratna

Ogelang untuk usaha pajak hotel kategori rumah kos sebesar Rp. 250.000. untuk masa pajak 1 Agustus 2016 - 31 Agustus 2016. Dispenda Bitung tidak membuat jurnal saat menerima pembayaran pajak hotel.

Jurnal yang seharusnya dibuat oleh Dispenda Bitung untuk mencatat transaksi tersebut adalah:

Tabel 4.3 Jurnal Transaksi 1

\begin{tabular}{|c|c|c|c|}
\hline Tanggal & Nama Perkiraan & Debit & Kredit \\
\hline 20 September 2016 & Kas & Rp. 250.000 & \\
\hline & Pendapatan & & Rp. 250.000 \\
\hline
\end{tabular}

2. Pada tanggal 13 Desember 2016 diterima pembayaran pajak dari Kos Paal II Inn untuk usaha pajak hotel kategori rumah kos sebesar Rp. 225.000. Dispenda Manado tidak membuat jurnal saat menerima pembayaran pajak hotel.

Jurnal yang seharusnya dibuat oleh Dispenda Manado adalah untuk mencatat transaksi tersebut adalah:

Tabel 4.4 Jurnal Transaksi 2

\begin{tabular}{|c|c|c|c|}
\hline Tanggal & Nama Perkiraan & Debit & Kredit \\
\hline 13 Desember 2016 & Kas & Rp. 225.000 & \\
\hline & Pendapatan & & Rp. 225.000 \\
\hline
\end{tabular}

Pencatatan penerimaan pajak hotel kota Bitung yang dilakukan oleh dinas pendapatan daerah kota Bitung yaitu dengan mencatat setiap penerimaan pajak yang disetorkan wajib pajak dalam sebuah buku khusus data penerimaan pajak hotel, tetapi tidak dibuat jurnal atas transaksi tersebut. Sedangkan pencatatan penerimaan pajak hotel kota Manado yang dilakukan oleh dinas pendapatan daerah kota Manado yaitu dengan mencatat setiap penerimaan pajak yang disetorkan wajib pajak dalam sebuah buku umum data penerimaan pajak daerah, tidak seperti yang dilakukan di dinas pendapatan daerah kota Bitung. Dinas pendapatan kota Manado juga tidak membuat jurnal dalam pencatatan pajak hotel.

\section{Pelaporan Penerimaan Pajak Hotel}

Laporan penerimaan pajak hotel di kota Bitung pada tahun 2011-2014 mengalami peningkatan, sedangkan pada tahun 2014-2015 terjadi penurunan penerimaan pajak hotel. Tahun 2011 merupakan tahun penerimaan pajak terendah dan tahun 2014 merupakan tahun penerimaan pajak hotel tertinggi. 
Laporan penerimaan pajak hotel di kota Manado pada tahun 2011-2015 menunjukkan peningkatan setiap tahunnya. Tahun 2011 merupakan tahun yang penerimaan pajak hotel terendah dan tahun 20115 merupakan tahun penerimaan pajak hotel tertinggi.

\section{KESIMPULAN DAN SARAN \\ 5.1. Kesimpulan}

Berdasarkan penelitian yang dilakukan oleh peneliti terhadap pencatatan dan pelaporan yang dilakukan di dinas pendapatan daerah kota Bitung dan di dinas pendapatan daerah kota Manado, di dapati bahwa pencatatan penerimaan pajak hotel kota Bitung yaitu mencatat setiap penerimaan pajak yang disetorkan wajib pajak dalam sebuah buku khusus data penerimaan pajak hotel dan tidak dibuat jurnal atas transaksi tersebut. Pencatatan penerimaan pajak hotel kota Manado yaitu dengan mencatat setiap penerimaan pajak yang disetorkan wajib pajak dalam sebuah buku umum data penerimaan pajak daerah dan tidak membuat jurnal dalam pencatatan pajak hotel.

Berdasarkan penelitian yang dilakukan oleh peneliti di dapati bahwa data laporan realisasi anggaran penerimaan PAD khususnya pajak hotel, untuk dinas pendapatan daerah kota Manado penerimaan pajak hotelnya lebih besar jumlahnya di bandingkan dengan penerimaan pajak hotel dinas pendapatan daerah kota Bitung karena jumlah wajib pajak hotel kota Manado lebih banyak dari wajib pajak hotel di kota Bitung.

\subsection{Saran}

Berdasarkan hasil penelitian dan kesimpulan yang dilakukan peneliti di dinas pendapatan daerah kota Bitung dan di dinas pendapatan daerah kota Manado, maka peneliti memberikan saran yaitu:

a. Untuk pencatatan penerimaan pajak di dinas pendapatan kota Manado sebaiknya dicatat dalam buku khusus data pajak hotel.

b. Untuk pencatatan transaksi penerimaan pajak hotel di dinas pendapatan daerah kota Bitung dan dinas pendapatan daerah kota Manado sebaiknya dibuat jurnal untuk setiap transaksi.

\section{DAFTAR PUSTAKA}

Badriah, Huriah, 2015. Akuntansi Biaya. Indeks. Jakarta.

Hendra, 2014,"Penerapan Akuntansi Pajak Penghasilan Pasal 23 pada PT. Golden Mitra Inti

Perkasa", Jurnal EMBA. Vol. 2 No. 1. ISSN 2303-1174.

Mardiasmo. 2011. Perpajakan. Andi offset. Yogyakarta.

Mardiasmo. 2013. Perpajakan Edisi Revisi. Andi Offset, Yogyakarta.

Mulyono, Djoko. 2010. Akuntansi Pajak dan Ketentuan Umum Perpajakan. Andi, Yogyakarta

Peraturan Daerah Nomor 1 Tahun 2013 kota Bitung tentang Pajak Daerah

Peraturan Daerah Nomor 2 Tahun 2011 kota Manado tentang Pajak Daerah

Samryn, L. M. 2012. Pengantar Akuntansi. PT. RajaGrafindo Persada. Jakarta

Sugiyono. 2011. Metode Penelitian Pendidikan. ALFABETA. Bandung .

Sumarsen, Thomas. 2013. Perpajakan Indonesia. PT. Indeks Kelompok Gramedia. Jakarta.

Watung, L, R, 2016. "Analisis Penerapan Pajak dengan Witholding Tax System terhadap

Pajak Penghasilan Pasal 4 Ayat 2 pada PT. Bank Sulutgo di Kota Manado", Jurnal

EMBA. No. 1 Vol. 4. ISSN: 2303-1174. Hal 916-923.

Wungkar, D, M, 2016. "Penerbitan Surat Paksa Sebagai Upaya Penagihan Aktif dan Kontribusinya terhadap Pencairan Tunggakan Pajak pada KPP Pratama Kotamobagu", Jurnal EMBA. No. 1 Vol. 4. ISSN 2303-1174. Hal 656-666. 